\author{
Građevinski materijali i konstrukcije \\ Building Materials and Structures \\ journal homepage: www.dimk.rs \\ doi: 10.5937/GRMK2102093R UDK: 666.972 \\ Preliminary report
}

\title{
Compressive strength of green concrete with low cement and high filler content
}

\author{
Andrija Radović ${ }^{* 1)}$, Snežana Marinković ${ }^{2)}$, Aleksandar Savić ${ }^{2)}$ \\ 1) University of Priština in Kosovska Mitrovica, Faculty of Technical Sciences, Knjaza Miloša 7, 38220 Kosovska Mitrovica, Serbia \\ 2) University of Belgrade, Faculty of Civil Engineering, Bulevar Kralja Aleksandra 73, 11000 Belgrade, Serbia
}

\begin{abstract}
Article history
Received: 15 April 2021

Received in revised form: 26. May 2021

Accepted: 31 May 2021

Keywords

green concrete,

limestone filler,

low cement content, compressive strength, workability
\end{abstract}

Available online: 30 June 2021

\begin{abstract}
It is estimated that by the end of the current decade, about $26 \%$ of clinker will be replaced by suitable alternative materials, among which limestone filler probably has the greatest potential due to its wide availability and relatively low price. Although codes allow as much as $35 \%$ of clinker to be replaced by limestone filler, the amounts used in practice are far lower and average only 6-7\% globally. In order to use the great potential of fillers, it is necessary to know the key parameters that affect the properties of green concrete with low cement and high filler content in fresh and hardened states. Therefore, thorough literature review was conducted, followed by design of 18 concrete mixtures, in order to analyze the effects of the percentage of cement replacement, water-cement ratio, but also the particle size of the applied filler. The results of experimental research show that at the same w/c ratio there is an increase in compressive strength with increasing percentage of cement replacement and that it is possible to make medium-strength concrete with significantly reduced amount of cement $180 \mathrm{~kg} / \mathrm{m}^{3}$ compared to traditional concrete. Thus, economic benefits can be achieved, but also the negative impact of the concrete industry on the environment can be reduced. Unfortunately, the workability of such mixtures can be impaired to the extent that their practical application is prevented, so it is necessary to take further steps to solve this problem.
\end{abstract}

\section{Introduction}

The human population lays claim to use all natural resources and healthy environment; but it also should not ignore the moral obligation - not to deny those same rights to some future generations. The use of fossil fuels (including cement production) is the main problem for creating the greenhouse effect and climate change. Moreover, it is estimated that about $7-8 \%$ of total $\mathrm{CO}_{2}$ emissions of anthropogenic origin is a consequence of cement production, with a further tendency to grow, despite the constant improvement of technology and increasing efficiency $[1,2]$.

In addition, the research of some authors [3-5] indicates that by the end of the current decade the world production of cement will exceed five billion tons, which, unlike in 1990, when one billion was produced, represents an increase of as much as five times. The direct consequence of this activity is an increase in global $\mathrm{CO}_{2}$ emissions for additional $1-2 \%$ [6]. Having this in mind, the cement industry is facing numerous challenges including increasing pressures from public. The biggest concern is the use of a large amount of relatively expensive energy, which participates in the total production costs with $30-50 \%$ [5], and the final output is a product with significant $\mathrm{CO}_{2}$ emission. Accordingly, the concrete industry can play one of the key roles on the path of sustainable development and rational use of resources.

In order to preserve the competitiveness of concrete as the most used construction material in the future, it is necessary to take appropriate measures to promote sustainable development and environmental protection in this field. One has to take into account the huge amount of cement produced, as well as the fact that the production of one ton of pure Portland cement emits about $860 \mathrm{~kg}$ of $\mathrm{CO}_{2}$ into the atmosphere [7-9]. Therefore, it is concluded that even a small replacement of a certain amount of cement with alternative materials can have a significant global contribution in solving these problems. About $60 \%$ of the total share of $\mathrm{CO}_{2}$ emissions, is the result of the decomposition of limestone during the decalcification process, while the remaining $40 \%$ is the result of burning fossil fuels to obtain the required amount of energy in the production process $[10,11]$.

Corresponding author:

E-mail address: andrija.radovic@pr.ac.rs 
In 2017, the average clinker content in cement was around $77 \%$, and by the end of the decade, a reduction of an additional $3 \%$ is planned, which means that $26 \%$ of clinker will be replaced by suitable alternative materials [11]. These materials can be artificial (fly ash, blast furnace slag) or natural (limestone, quartz and other). The previous attention of researchers was mainly focused on the application of industrial by-products [12-14], primarily because of their appropriate pozzolanic properties. However, the latest research in the world [15-17] also show a very large potential of inert and weakly reactive materials, which are mainly different types of fine powder materials (fillers).

Potential problems and major limitation in the wider application of alternative binders are the limited quantities of waste materials based on industrial by-products that are in constant decline [18] and the relatively high cost of other supplementary cementitious materials. On the other hand, the potential of fillers is further enhanced by relatively low unit price, wide availability (Figure 1), and simple production processes with minimal $\mathrm{CO}_{2}$ emissions of only $8 \mathrm{~kg} / \mathrm{t} \mathrm{[19],} \mathrm{so}$ we should expect higher demand for these materials in the future.

As the largest cement producer in Serbia, the company Lafarge Srbija Ltd. managed to reduce the amount of $\mathrm{CO}_{2}$ emitted per ton of cement from 1990 to 2014 by $21 \%$, and by 2030 a reduction of an additional $19 \%$ is planned [20].

\section{A brief overview of historical development and regulations}

There is no universal definition of filler [15]. It can be said that they are very fine powdery materials that are mostly inert or weakly reactive $[15,21]$, and can be of different origin and mineralogical composition. Limestone fillers are the most common and most widely used [18], but equally satisfactory results can be found in the literature when using quartz fillers [22]. However, the higher price of quartz fillers should be also considered, which is mainly due to the more complex technological process of production, less availability, but also their serious harm (potentially cancerogenic) to human health should be taken into account $[18,23]$.

The first use of fillers as a replacement for cement was recorded at the beginning of the last century [15]. During the construction of Arrowrock and Elephant Butte Dams (Figure 2 ), in order to reduce the internal temperature due to excessive heat of hydration and shrinkage of these massive concrete structures, almost $50 \%$ of the cement was replaced by ground granite and sand extracted during construction $[15,24,25]$.

These impressive engineering endeavours were followed by the first significant long-term tests of the mechanical properties and durability of concrete in which cement was replaced by fine powder materials [26]. However, the more serious application of fillers in the cement industry has been waiting for almost fifty years [3]. Due to the consequences of the great oil crisis in 1973, the somewhat larger use of fillers as a substitute for clinker began. A period of standardization [15] followed, as well as the legally regulated application of fillers in the cement industry. In the beginning, the regulations were quite conservative and these were very modest figures (up to $5 \%$ ), but over time the regulations were innovated and allowed an increasing percentage replacement of clinker by up to $35 \%[27,28]$. However, it was common to find standards that were probably nonconservative at the time of publication, because of all the uncertainties related to the technology of filler production, Figure 3. Thus, in the Spanish standard from 1960, 10\% of fillers were allowed, and already in 1975 it was increased to $35 \%$, which is still an upper limit for most countries.

A review of world standards found that in 1991, about 25 countries around the world allowed only $5 \%$ of cement fillers[28], while in 1993 about 40 countries around the world adopted a limit of $20 \%$ [27].

Today, many modern regulations in this area limit the maximum percentage of fillers (exclusively of limestone origin) in cement. It can be concluded that the regulations of some of the most developed countries still have rather conservative restrictions, maximum of $15 \%$, and these countries are: China (2007), Canada (2008) and USA (2012) [15].

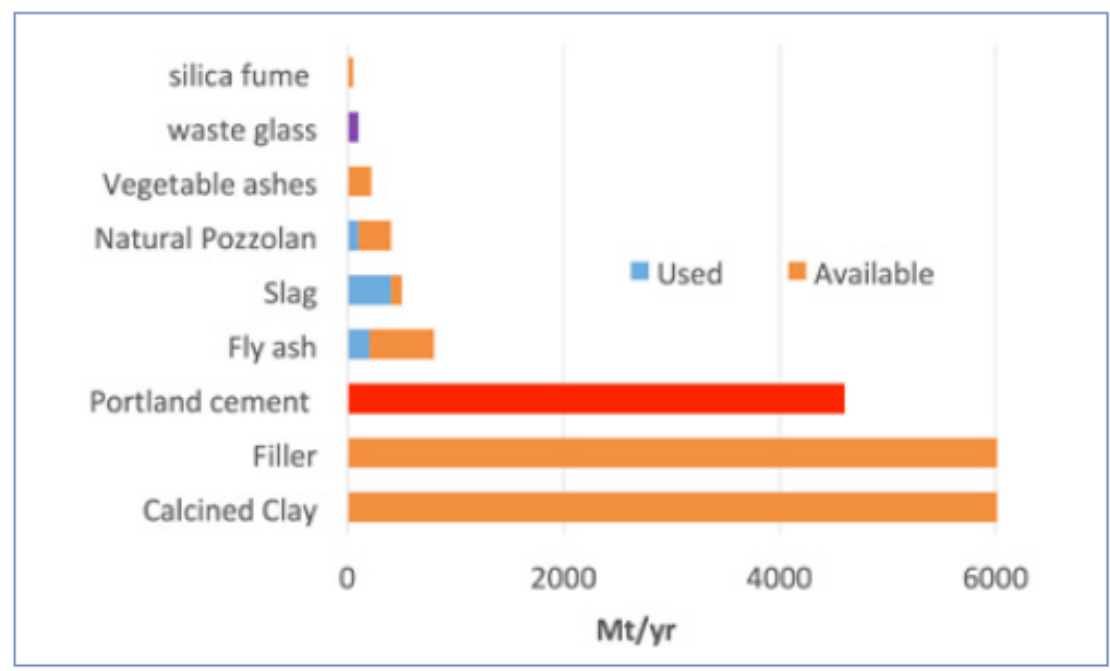

Figure 1. Estimated availability and current use of certain alternative cementitious materials in the world [3] 

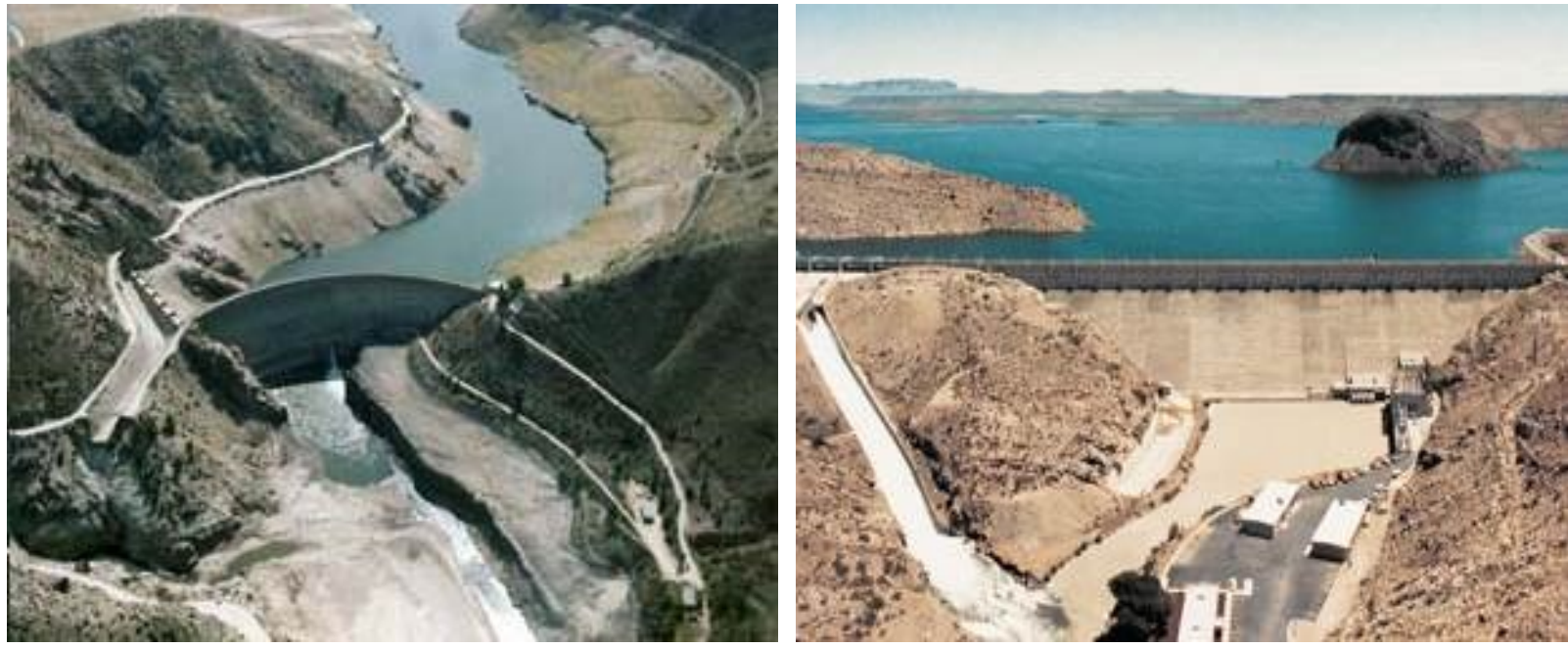

Figure 2. Arrowrock Dam on Idaho's Boise River (left) and Elephant Butte Dam on the Rio Grande (right) [24,25]

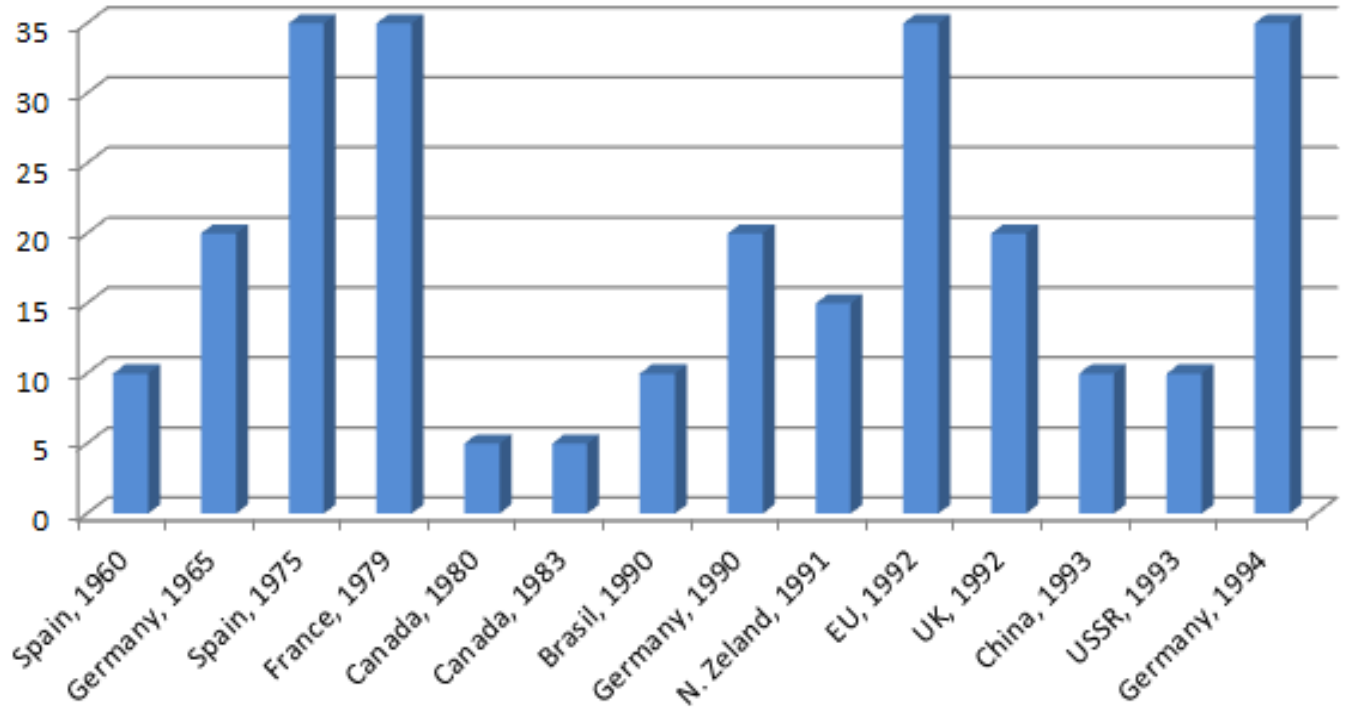

Figure 3. The maximum percentage content of limestone filler in cement and year of publication of the standard over the period 1960-1995.

Unfortunately, according to World Business Council for Sustainable Development (WBCSD)[29], the quantities of fillers that are applied in practice are far below the maximum allowed values from the regulations. Average limestone filler content in cement according to WBCSD [29] in the countries of the European Union, as well as in the whole world, by years is shown in Figure 4.

A similar trend is observed in Europe and in the world. Since the beginning of the 1990s, there has been a very slight increase to some $6-7 \%$ and from 2011 until today it remains practically constant. The same applies when it comes to other alternative materials (Figure 5), for the countries of the European Union. It is obvious that limestone filler is the most represented mineral addition in cement together with slag, but its content is even five times lower than the allowed values [30].

As a positive example, Morocco, Algeria, and Tunisia should be pointed out; in these countries, the average content of limestone filler in cement is the highest in the world and from 2011 until today it is about $20-22 \%$. [29]. In addition, in these countries, the limestone filler is twice as common as all other mineral additives combined. 


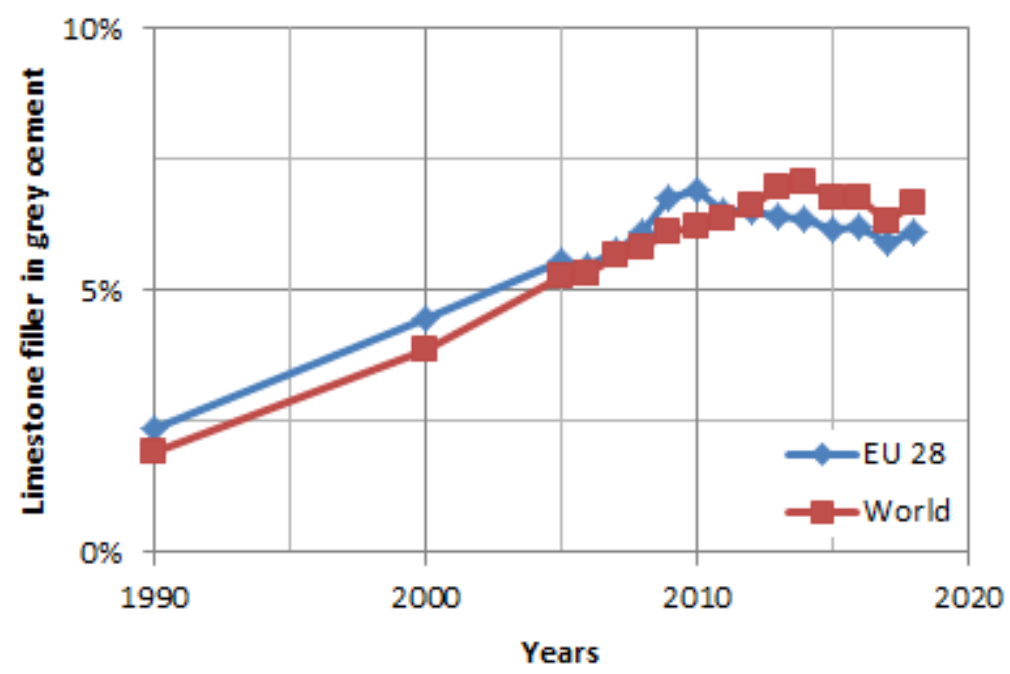

Figure 4. Limestone filler content in cement (chronological development), data from WBCSD [29]

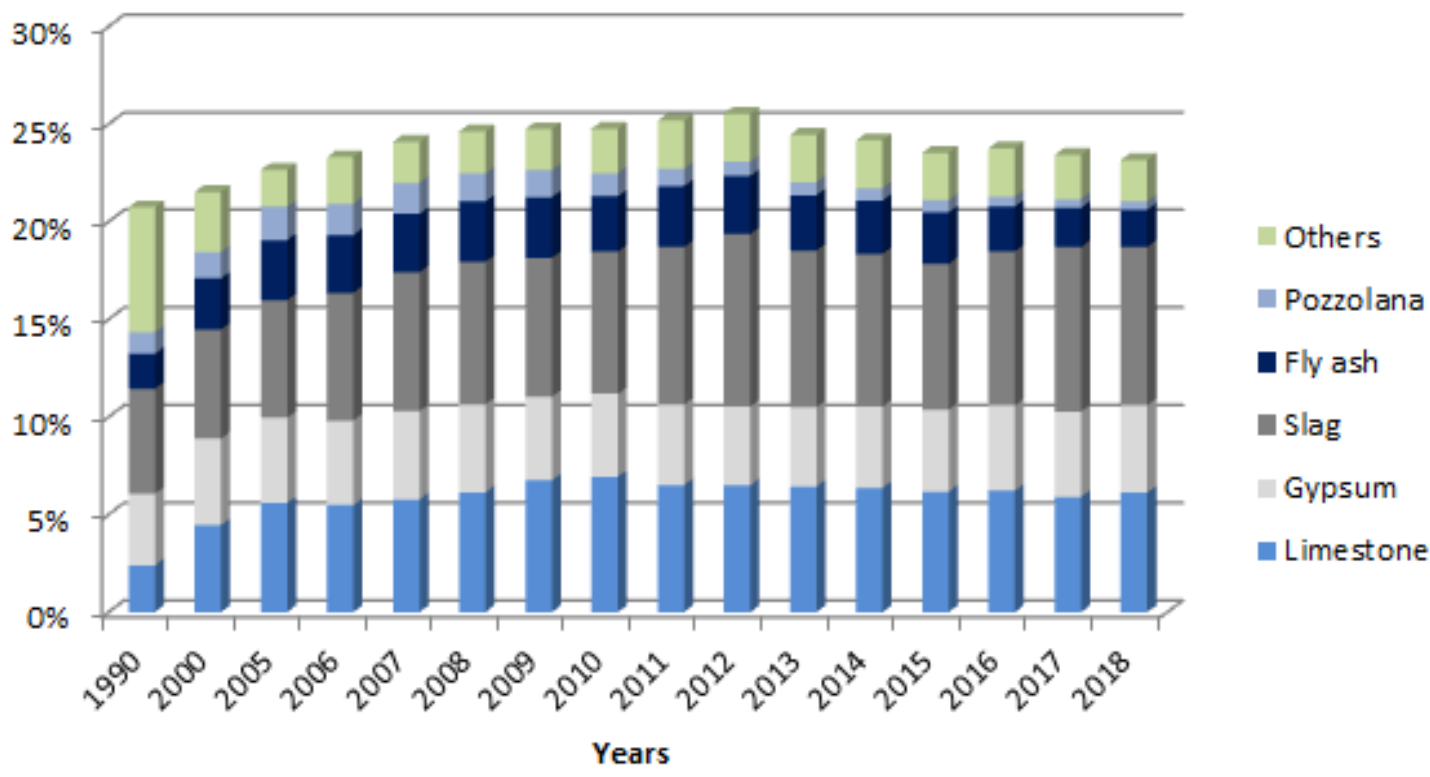

Figure 5. The percentage content of individual mineral additives in cement (chronological development), EU countries, data from WBCSD [29]

Here it should be noted that in addition to the maximum allowed content of limestone filler in cement, modern regulations introduce some additional restrictions. Thus, the EN 197-1 [30] defines the minimum mass content of calcium carbonate $\left(\mathrm{CaCO}_{3}\right)$ which must not be less than $75 \%$ of total filler content, while the clay content must not be more than $1.2 \mathrm{~g}$ per $100 \mathrm{~g}$ of filler. In the case of limestone used in cements, there are two designations, $\mathrm{L}$ and $\mathrm{LL}$ in dependence of the Total organic carbon content (TOC). In the case of L-limestone, this content must not exceed $0.5 \%$ of the weight of limestone, while in the case of LL-limestone this condition is stricter, and must not exceed $0.2 \%$. In the EN 12620 [31] certain grading requirements are defined for filler aggregate, table 1.
Table 1. Grading requirements for filler aggregate, EN 12620 [31]

\begin{tabular}{|c|c|}
\hline $\begin{array}{c}\text { Particle size } \\
{[\mathrm{mm}]}\end{array}$ & $\begin{array}{c}\text { Passing by mass } \\
{[\%]}\end{array}$ \\
\hline 2 & 100 \\
\hline 0.125 & $85-100$ \\
\hline 0.063 & $70-100$ \\
\hline
\end{tabular}




\section{Influence of fillers on the properties of fresh and} hardened concrete - a literature review

Experimental tests on the filler application have gained substantial importance after technology modernization and technological production process improvement, which is especially evident in the last 10-15 years. The influence of the filler on the properties of concrete in a fresh and hardened state can be crucial for practical application, so it is necessary to study it in detail, in order to take advantage of all the positive effects, and hopefully reduce negative ones.

\subsection{Workability of fresh concrete}

Divided opinions about the influence of fillers on the workability of concrete mixtures can be found mainly in older papers [27,28], some authors reporting a positive [32], and others a negative experience [33]. Analysing the replacement of up to $40 \%$ of cement with fillers, the authors [33] conclude that in the case of water-cement (w/c) ratio was constant, workability slightly decreases when the filler content increases, due to the increase of specific surface of aggregate, and vice-versa: when the water-powder $(\mathrm{w} / \mathrm{p})$ ratio is constant, workability improves with increased filler content. Because of that, the same amount of water is adopted in all mixtures, i.e. the water-powder ratio was constant, $w / p=0.5$. On the other hand, replacing up to $20 \%$ of cement, in [34], there was no change in the workability of concrete mixtures (for the same w/c), regardless of the filler content. In recent research [32] positive effects (increase of limestone resulted in decrease of superplasticizer demand for the same flow value) are dominantly recorded. This is probably a consequence of the mentioned modernization and improvement of technological process of filler production, primarily the improvement of the grinding process. In addition, the application of new generation chemical additives - high-performance superplasticizers provides high water reduction. Obtaining a proper range of very fine particles is primarily reflected in the increase in packing density, which leads to the reduction of voids to be filled with water [15]. This allows additional reduction of water. However, it is practically always necessary to apply a certain amount of superplasticizer, in order to preserve the workability of the mixture [32,35]. Rezvani et al. [32] deals with workability of concrete, in which as much as $65 \%$ of cement is replaced by filler. The authors state that the reduction of water below a certain limit has a huge impact on workability. However, all mixtures with water-cement (w/c) ratio greater than 0.25 had satisfactory workability (plastic viscosity was less than $50 \mathrm{Nm} /(\mathrm{m} / \mathrm{s}))$. In addition, the authors determined the optimal amount of paste (water, cement, and filler) and it was $320 \mathrm{~kg} / \mathrm{m}^{3}$ in all mixtures, while the superplasticizer is dosed as needed, until the mentioned workability of the mixture is achieved. A similar procedure was applied in [36,37], where the amount of paste was 20$34 \%$ of the total volume of concrete, while the superplasticizer was dosed in the amount of $0.5-2 \%$ by the weight of powder component, in order to provide the desired slump of $20 \mathrm{~cm}$.
In the same way, Proske et al. [38] found that the content of fine particles $(<0.125 \mathrm{~mm})$ should be at least $430 \mathrm{~kg}$ per 1 $\mathrm{m}^{3}$ of concrete $\left(\mathrm{kg} / \mathrm{m}^{3}\right)$ for maintaining satisfactory workability. In addition, it was found that the amount of water can be reduced (which is necessary if the goal is to obtain high compressive strength) to a minimum of $125 \mathrm{~kg} / \mathrm{m}^{3}$. Therefore, workability of the mixture must be corrected by adding high-performance superplasticizers $\left(2-6.5 \mathrm{~kg} / \mathrm{m}^{3}\right)$. Additionally, the same authors, in order to obtain better workability of the mixture, suggest the use of fillers of higher fineness, which is in agreement with the other research [39].

\subsection{Influence of filler on the compressive strength}

\subsubsection{Cement replacement percentage and particle size} distribution

The compressive strength of concrete is probably the most important parameter in the overall assessment of concrete quality and practically all physical and mechanical properties can be expressed in the function of this property.

Analysis of the replacement up to $40 \%$ of cement with limestone filler found that the content of filler up to $10 \%$ has insignificant effect on the decrease in strength (moreover, slight increase was observed), while for higher replacement percentages there is a gradual reduction in compressive strength [33]. According to the author, this is a consequence of intergranular voids being filled by the filler and additional portion of filler begins to take place of the main aggregate grain. Although the term water-binder $(w / b)$ ratio is mostly used, which was constant in all mixtures and it was 0.5 , which is actually the $w / p$ ratio. Other papers $[34,40,41]$ also use the approach of adopting $w / b=$ const, and as it is about inert or weakly reactive materials, a certain amount of excess water that cannot hydrate will appear, which results in an increase of the real w/c ratio, and wrong conclusions can be drawn, Figure 6 . Therefore, one of the important conclusions is that when replacing cement with filler, the w/c ratio should be kept constant or reduced in the case of a large replacement, in order to avoid a reduction in compressive strength $[35,38]$.

Volumetric replacement of cement paste (cement + water) with limestone filler of similar particle size was performed by Chen et al. $[35,36]$. In these studies, the filler volume was given as a percentage of the total concrete volume and it was $0-12 \%$, while the $\mathrm{w} / \mathrm{c}$ ratio was in the range of $0.35-0.6$. At the same w/c ratio, an increase in strength with an increase in filler content was recorded, and it was higher in samples with a higher percent of replacement and with higher w/c ratios reaching $25-30 \%$ in some cases. Workability was provided by the use of plasticizers $(1-2 \%$ by the weight of the powder component), and the slump was over $20 \mathrm{~cm}$. Researchers from Germany came to the similar conclusions $[17,38,42-45]$, when replacing a large amount of cement (up to $50 \%$ ). For the same w/c ratio, samples containing fillers had higher strengths than the reference ones. The difference is greater in samples with higher filler content. High-performance superplasticizers $\left(2-7 \mathrm{~kg} / \mathrm{m}^{3}\right)$ were used to obtain the desired workability of the mixture (flow table diameter $490-550 \mathrm{~mm}$; plastic viscosity 50 $\mathrm{Nm} /(\mathrm{m} / \mathrm{s}))$ 


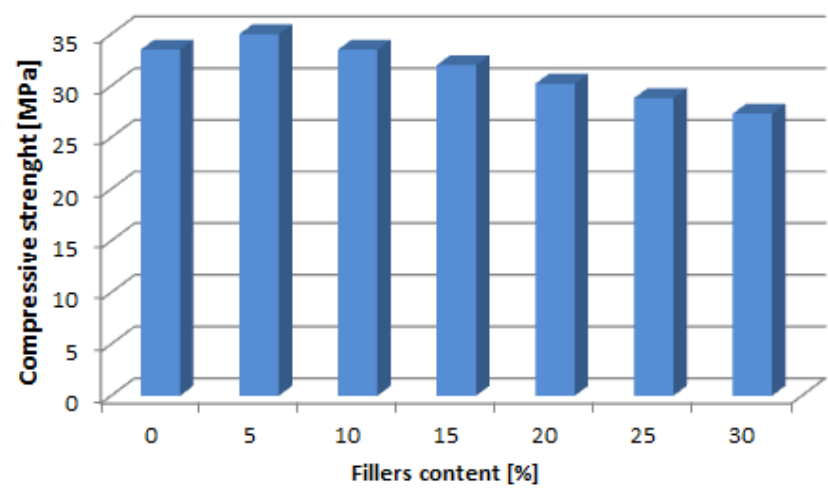

Figure 6. Compressive strength of the samples as a function of \% cement replacement, samples measuring $10 \times 10 \times 10 \mathrm{~cm}$, data from Bederina et al. [33]

John et al. [15] states that it is possible to replace as much as $75 \%$ of the binder (cement + other binders) with fillers and for the amount of binder of only $100 \mathrm{~kg} / \mathrm{m}^{3}$, extremely high strengths, up to $90 \mathrm{MPa}$, can be obtained. However, this is a serious problem, because, in order to achieve this, a large reduction of water and application of new generation superplasticizers are necessary. Even then, it is difficult to achieve and control acceptable workability of the mixture. The authors of this paper did not establish a possible relationship between the compressive strength and the $w / p$ ratio, but a certain relationship between the compressive strength and the $\mathrm{w} / \mathrm{c}$ ratio was established.

The fineness, i.e. the particle size distribution curve of the filler also has a significant effect on the compressive strength $[21,38,41,43]$. Practically all studies have found an increase in strength about $10-20 \%$ when using fillers of higher fineness. This is more pronounced in samples with higher percentages of replacement and in some cases was as much as $50 \%[38,43]$. This phenomenon is probably a consequence of the higher particle packing optimization.

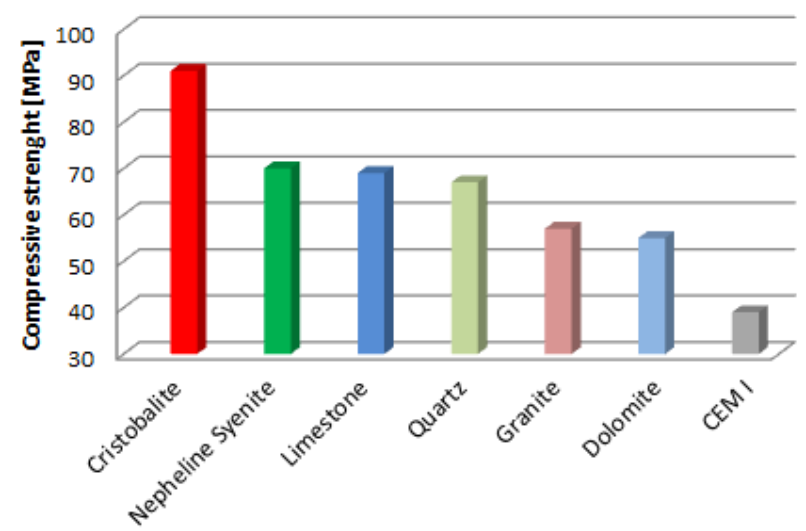

\subsubsection{Mineral composition of fillers}

The study by Muller et al. [46] is one of the most important researches in which quartz fillers were used. In order to increase the range of fine particles, the replacement of cement $(4-10 \%$ of the total volume) was performed using two fillers of different particle sizes. Compaction - Interaction Packing Modelproposed by Fennis [47] for increasing the particle packing was applied, and types of cement of relatively large strength classes, CEM I 52.5R (68MPa) and specially produced cement of increased fineness of grinding (micro cement 106.3 MPa) were used. In some mixtures, the amount of cement was only about $110 \mathrm{~kg} / \mathrm{m}^{3}$. The obtained concrete compressive strengths ranged from $60 \mathrm{MPa}$, up to $102 \mathrm{MPa}\left(\mathrm{CEM}\right.$ I $\left.268 \mathrm{~kg} / \mathrm{m}^{3}\right)$. Polycarboxylate-based superplasticizers $\left(5-6 \mathrm{~kg} / \mathrm{m}^{3}\right)$ were used, w/c ratios were in the range of $0.4-0.7$, but nevertheless workability of mixtures in which the amount of cement was less than $138 \mathrm{~kg} / \mathrm{m}^{3}$ was not reported.

The influence of fillers of different origin, as well as the fineness of the mill was analysed in [22]. Quartz fillers (finer and coarser than cement) were used in this study, as well as syenite and wollastonite fillers, which are also finer than cement, and up to $50 \%$ of the cement was replaced. The reference samples had the lowest strength, and the increase in filler fineness was accompanied by an increase in strength, for practically all w/c ratios, regardless of mineral composition.

Similar conclusions have been drawn by other researchers [40]. When replacing $50 \%$ of cement with fillers of different mineral compositions, and a constant $\mathrm{w} / \mathrm{c}$ ratio of 0.5 , an increase in compressive strength of as much as 50 to $144 \%$ was observed in relation to the reference concrete mixture, Figure 7 (left).

The influence of the density of the filler on the initial volumetric concentration of water is very important and it is reflected in the porosity of the hardened paste [40], Fig. 7 (right). Fillers with lower density will result in a higher content of powder component, and as it seems, higher strength, Figure 7 (right).

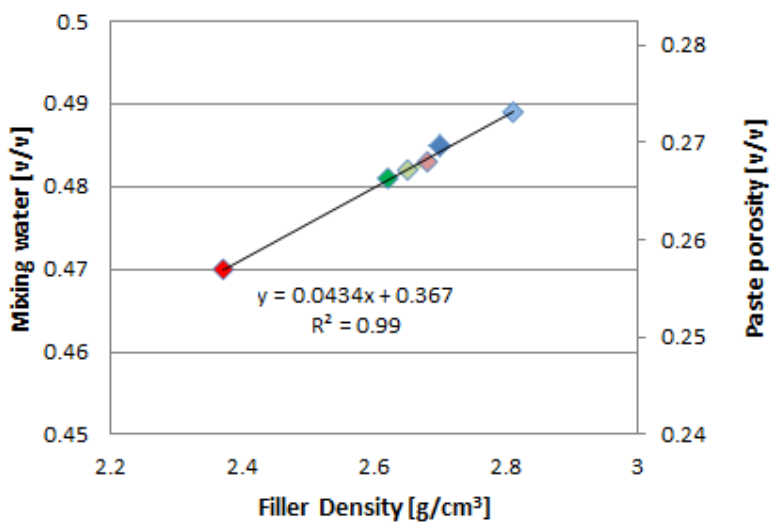

Figure 7. Influence of mineral composition of filler on compressive strength (left), required amount of water and porosity (right), data from Damineli [40] 


\section{Objectives and methodology}

The literature review shows a clear trend towards improved efficiency in cement production, primarily the development of new and cleaner technologies that may require significant investment. One way to achieve these goals may be simply replacing a certain amount of cement with a cheaper and cleaner product - filler.

In this study, different green concrete mixtures with low cement and high filler content were made for structural application. Green, i.e. eco-friendly, concrete has a reduced negative environmental impact compared to conventional concrete. Notwithstanding the lower binder content, the concrete performance had to be conserved.

Workability must be satisfactory for practical application, so the slump-test value according to SRPS EN 12350-2 [48] was chosen to be more than $15 \mathrm{~cm}$ (class S4), typical for pumping concrete. The mean compressive strength at 28 days had to be in the range $38-45 \mathrm{MPa}$, in order to obtain compressive strength class $\mathrm{C} 25 / 30$ or $\mathrm{C} 30 / 35$, providing the structural applications of these concretes.

An extensive test program was conducted including testing physical and mechanical properties of the fresh and hardened concrete. One of the aims of this study was to show that different fillers can be efficiently used to reduce cement amount and concequently negative environmental impact. In addition, the influence of different percentage of cement replacement with filler, as well as the amount of water in the mixture (through w/c ratio) was observed. In addition, the influence of filler particle size was analysed on a limited number of mixtures.

\section{Experimental program}

\subsection{Materials}

In order to eliminate the influence of other mineral additives, pure Portland cement ( $\max 5 \%$ additives) of the middle class (CEM I 42.5R) with accelerated strength gain was used for experimental tests. Two limestone fillers (L), different particle sizes, and one quartz (Q) filler were used as cement replacements. Particle size distribution of the cement and filler are shown in Figure 8. The figure shows that the filler in the L1 mark has much finer particles than cement, while the other two fillers $L 2$ and $Q$ have much larger particles than cement and fail to meet the requirements in terms of grading requirements from EN 12620 [31], Table 1. The solid green line in the Figure shows these constraints, while the dashed green line represents a linear extrapolation. Thus, the analysis partially covers the impact of filler grading size, especially those that go beyond the recommendations of the standard.

The chemical composition of the applied limestone fillers is in accordance with the standard EN 197-1 [30] $\left(\mathrm{CaCO}_{3}\right.$ content is $98 \%, \mathrm{MgCO}_{3}$ is $1.4 \%, \mathrm{Fe}_{2} \mathrm{CO}_{3}$ is $0.1 \%$ and $\mathrm{HCl}$ insoluble content is $0.5 \%$ ). Unfortunately, the chemical composition of the quartz filler was not provided by the manufacturer.

In order to improve the workability of concrete mixtures, a second-generation superplasticizer (based on polycarboxylate) was used. The amount of superplasticizer is shown in relation to the mass of the powder component (cement + filler), Table 2.

A three - fraction river aggregate $\left(1850 \mathrm{~kg} / \mathrm{m}^{3}\right)$ was used, with nominal maximum aggregate size of $16 \mathrm{~mm}$, as well as water from the city water supply.

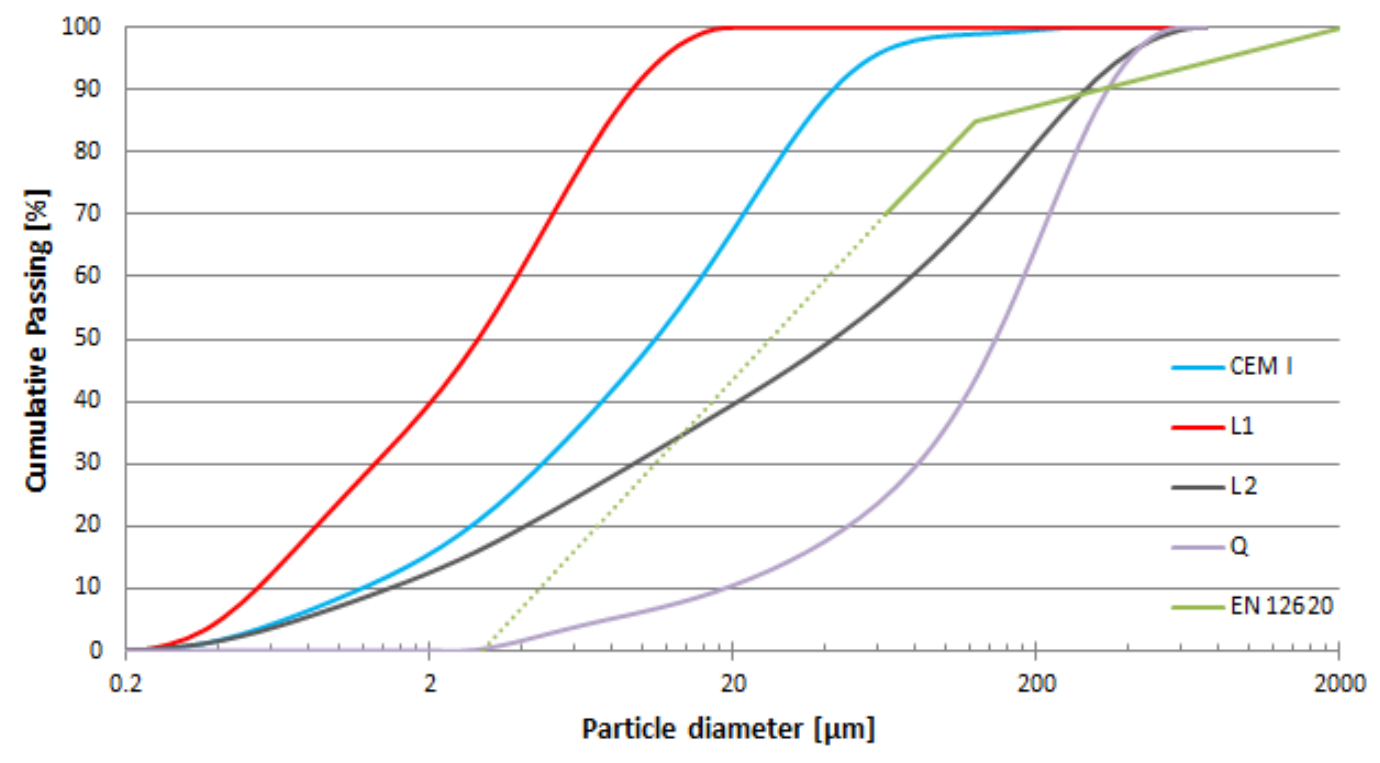

Figure 8. Particle size distributions of materials used 
5.2 Selection of the optimal particle size distribution of the aggregate

One of the initial and most important tasks is the correct choice of the particle size distribution of the aggregate. The individual fractions in the mixture are combined so that the total particle size distribution curve is as close as possible to certain reference curves (ideal grading curves, optimization curves). This achieves good particle packing of the aggregate and thus reduces the remaining space that needs to be filled with fine particles, i.e. paste (cement, water, and filler), Figure 9.

Probably the most well-known continuous optimization curve was proposed by Fuller $[22,49]$ and is given by equation (1):

$$
P_{(d)}=\left(\frac{d}{d_{\max }}\right)^{n}
$$

where:

$P_{(d)}$ - size cumulative distribution function $\mathrm{d}$ - particle diameter being considered [mm]

$\mathrm{d}_{\max }$ - the maximum particle size of the mix [mm]

$\mathrm{n}=0,5(0,45)$ - distribution modulus

This curve has been in use for over a hundred years and is still widely used today. The biggest disadvantage of the previous equation is that only the nominal maximum aggregate size is considered. Funk and Dinger propose modification on the basis of numerical simulations (for ideally spherical grains), equation (2), which also takes into account the size of the minimum particle size $\left(d_{\min }\right)$ in the mixture $[22,47]$. The value of the exponent that gives the highest packing density $n=0.37$ is proposed.

$$
P_{(d)}=\frac{d^{n}-d_{\min }^{n}}{d_{\max }^{n}-d_{\min }^{n}}
$$

The final particle size distribution curves of the aggregate and filler mixtures for concrete (designations of the concrete mixutures will be explained in detail in part 5.3) are shown in Figure 10. The target is the Fank and Dinger curve, equation (2), and the exponent value of 0.37 is adopted. For comparison, the Fuller curve, equation (1), is also shown. Significantly higher content of finer particles of the adopted mixtures is clearly observed in relation to the Fuller proposal $(n=0.5)$, but also slightly higher in relation to the Fank and Dinger proposal. The content of these particles is higher for higher percentage of cement replacement, because in these mixtures there is a more pronounced filler effect. It should be borne in mind that, as previously mentioned, the Fuller curve, equation (1), does not take into account fine particles (particle size distribution curve of the aggregate), and when powder components are added to the mixture, this and the curve described by the equation (2) will consequently converge.

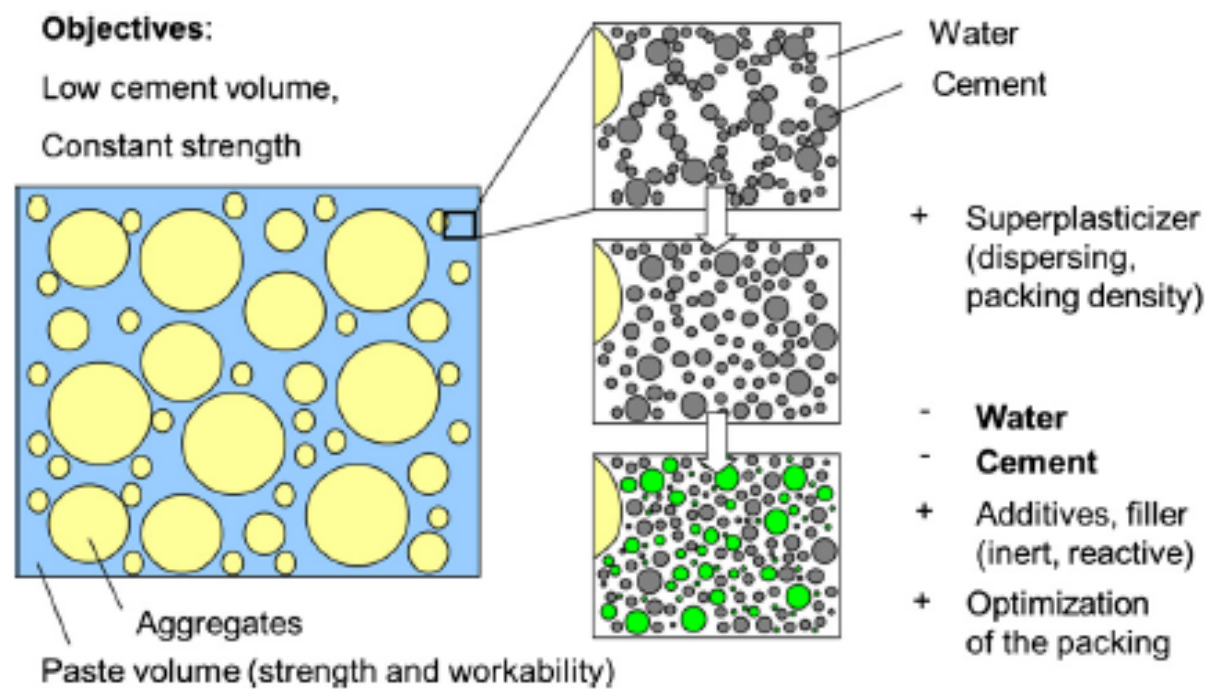

Figure 9. The principle of simultaneous reduction of cement and water with the addition of fillers [32] 
Compressive strength of green concrete with low cement and high filler content

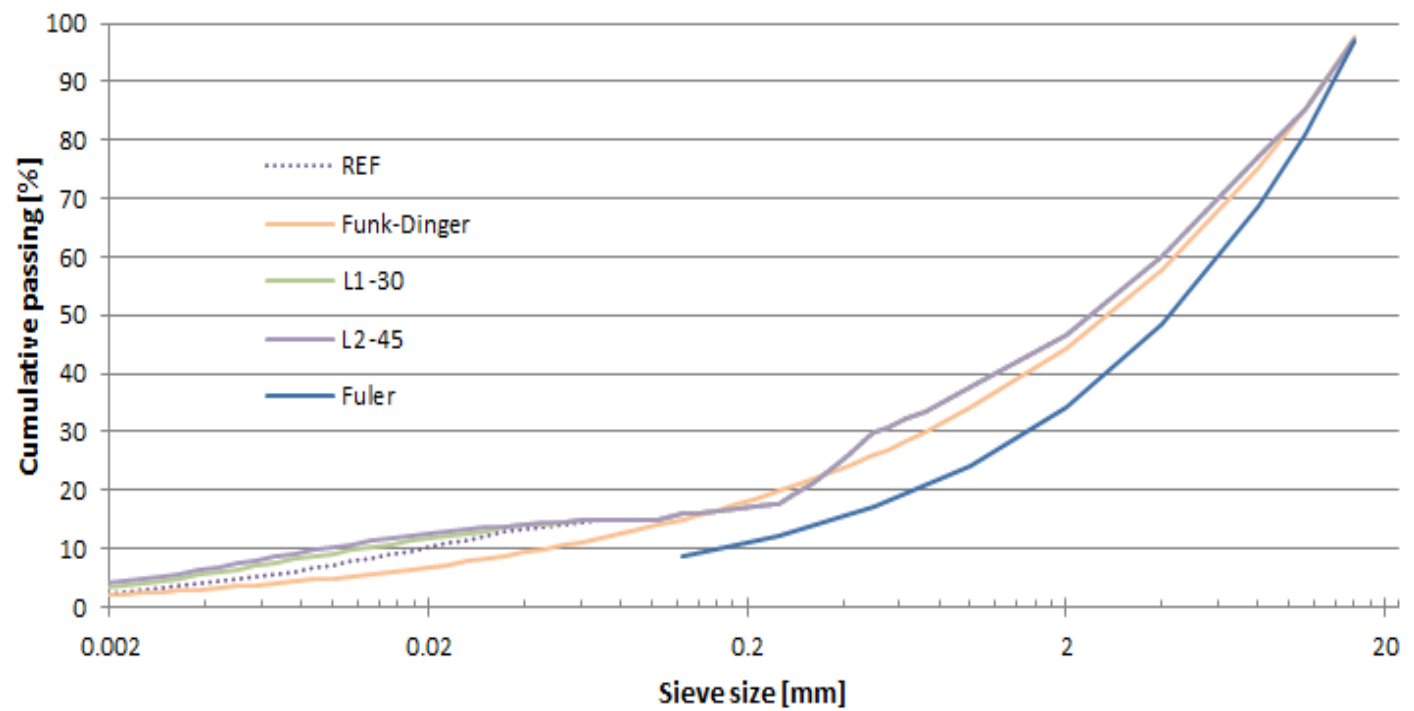

Figure 10. Particle size distribution of concrete mixtures

5.3 Concrete mix design

The composition of the designed concrete mixtures is shown in Table 2. Reference mixtures were made with $330 \mathrm{~kg} / \mathrm{m}^{3}$ of cement and w/c ratios of $0.54 ; 0.58 ; 0.62 ; 0.71$. This is followed by mixtures in which $30 \%$ and $45 \%$ of cement by weight are replaced by filler. Primarily, the influence of L1 filler, which is significantly finer than cement (8 mixtures), was analyzed, and in order to include the influence of different filler sizes, 3 more mixtures per filler were designed using $L 2$ and $Q$ fillers.

Table 2. Mix design of concrete

\begin{tabular}{|l|c|c|c|c|c|c|c|c|}
\hline \multicolumn{1}{|c|}{ Mix } & $\begin{array}{c}\text { Filler* } \mathrm{d}_{50} \\
{[\mu \mathrm{m}]}\end{array}$ & $\begin{array}{c}\text { CEM } \\
{\left[\mathrm{kg} / \mathrm{m}^{3}\right]}\end{array}$ & $\begin{array}{c}\text { Filler } \\
{\left[\mathrm{kg} / \mathrm{m}^{3}\right]}\end{array}$ & $\begin{array}{c}\text { Water } \\
{\left[\mathrm{kg} / \mathrm{m}^{3}\right]}\end{array}$ & $\begin{array}{c}\text { S.plast. } \\
\%\end{array}$ & w/c & w/p & Slump [cm] \\
\hline Ref-1 & $/$ & 330 & 0 & 177 & 0.5 & 0.54 & 0.54 & 23 \\
\hline Ref-2 & $/$ & 330 & 0 & 190 & 0 & 0.58 & 0.58 & 15 \\
\hline Ref-3 & $/$ & 330 & 0 & 204 & 0 & 0.62 & 0.62 & 17.5 \\
\hline Ref-4 & $/$ & 330 & 0 & 233 & 0 & 0.71 & 0.71 & 23.3 \\
\hline 30_L1_1 & 2.8 & 230 & 100 & 124 & 2 & 0.54 & 0.38 & $16.3^{\text {** }}$ \\
\hline 30_L1_2 & 2.8 & 230 & 100 & 134 & 1 & 0.58 & 0.41 & $19.5^{\text {** }}$ \\
\hline 30_L1_3 & 2.8 & 230 & 100 & 144 & 1 & 0.62 & 0.44 & 19.7 \\
\hline 30_L1_4 & 2.8 & 230 & 100 & 163 & 1 & 0.71 & 0.49 & 21 \\
\hline 30_L2_1 & 42.7 & 230 & 100 & 124 & 2 & 0.54 & 0.38 & 3.2 \\
\hline 30_Q_1 & 146.8 & 230 & 100 & 134 & 2 & 0.58 & 0.41 & 0.5 \\
\hline 45_L1_1 & 2.8 & 180 & 150 & 97 & 2 & 0.54 & 0.29 & 0 \\
\hline 45_L1_2 & 2.8 & 180 & 150 & 105 & 2 & 0.58 & 0.32 & $9.3^{\text {** }}$ \\
\hline 45_L1_3 & 2.8 & 180 & 150 & 112 & 2 & 0.62 & 0.34 & $17.7^{\text {** }}$ \\
\hline 45_L1_4 & 2.8 & 180 & 150 & 127 & 2 & 0.71 & 0.38 & $19.7^{* *}$ \\
\hline 45_L2_1 & 42.7 & 180 & 150 & 97 & 2 & 0.54 & 0.29 & 0 \\
\hline 45_L2_2 & 42.7 & 180 & 150 & 127 & 2 & 0.71 & 0.38 & 1 \\
\hline 45_Q_1 & 146.8 & 180 & 150 & 112 & 2 & 0.62 & 0.34 & 0.5 \\
\hline 45_Q_2 & 146.8 & 180 & 150 & 127 & 2 & 0.71 & 0.38 & 1 \\
\hline
\end{tabular}

* mean particle size

** shear slump, Fig. 11 

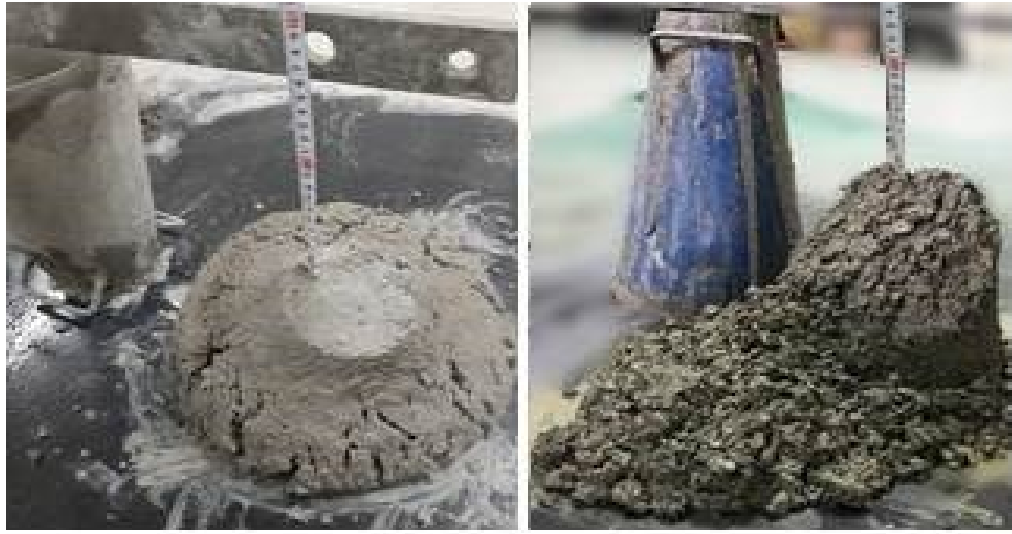

Figure 11. Possible forms of slump (true slump - left, shear slump - right)

Mixtures have the following designations: $X_{-} Y$ Y Z, where $X$ represents the percentage of cement replacement $(30,45)$, $Y$ denotes the filler used ( $L 1 ; L 2 ; Q)$, while $Z$ is the ordinal number of the mixture.

The mixing process lasted a total of $4 \mathrm{~min}, 1 \mathrm{~min}$ of dry mixing, in the next 30 s half of the water was added, then in the next $30 \mathrm{~s}$ the other half of water and superplasticizer; finally, mixing was continued for an additional $2 \mathrm{~min}$ to achieve the most homogeneous mixture. After mixing, the concrete is poured into moulds measuring $15 \times 15 \times 15 \mathrm{~cm}$, then compacted using vibrating table. After $24 \mathrm{~h}$, the samples are removed from the mould and cured in water at a temperature of $20 \pm 2^{\circ} \mathrm{C}$ until the day of testing.

\section{Results analysis and discussion}

\subsection{Workability of fresh concrete}

The standard slump method [48] was used as a parameter for quantitative assessment of concrete workability, picture 11. From Table 2, it can be seen that all reference mixtures, regardless of the $\mathrm{w} / \mathrm{c}$ ratio, and with a minimum amount of superplasticizers had very good workability (classes S4 and S5 according to [48]).

Mixtures with $30 \%$ cement replacement, in which the finest filler (L1) with a slightly higher amount of plasticizer was used, also had good workability, except for the mixture 30_L1_1 with the lowest w/c ratio at which the shear slump occurred. The mixture 30_L1_2 also had a shear slump, but it is realistic to expect that with the increase in the amount of superplasticizer (up to $2 \%$ ), its workability will significantly improve and shear slump will be avoided. In a mixture in which a quartz filler was used, probably due to the excessive particle size, an improvement in workability cannot be expected, even with an increase in the w/c ratio to a maximum of 0.71 and a relatively high content of superplasticizers.

In mixtures where $45 \%$ of cement has been replaced by a filler, there is an additional deterioration in workability (desired slump class was not achieved), regardless of the filler used. In any case, the mixtures with L1 filler had far better workability than the others, so it can be expected that the application of a larger amount of superplasticizers could further improve their workability, which can be uneconomical.
It may be better to look for a solution using a more powerful plasticizer. Larger fillers with large w/c ratios gave practically zero slump, while at lower w/c ratios the mixture is too dry.

It should be noted that the amount of paste in the volume of concrete was relatively low, $20-30 \%$, and that all mixtures that had this value above $25 \%$ had a proper slump, so the possible solution to the workability problem may be to increase the powder component.

\subsection{Compressive strength}

The shape and dimensions of the specimens for determining the compressive strength must be in accordance with [50], while the method of production and curing process are defined in [51].

The compressive strength test is performed at the age of 28 days in accordance with [52], by gradual application of load $(0.6 \pm 0.4 \mathrm{MPa} / \mathrm{s})$ to fracture. Three $15 \mathrm{~cm}$ cube samples were made for each mixture and the compressive strength was calculated as the mean of the measured values $\left(f_{\mathrm{cm}}\right)$. The test results are shown in Figures 12-17.

Figure 12 shows the dependence of the compressive strength of concrete and the w/c ratio. A significant decrease in strength with an increase in w/c is clearly observed. The percentage decrease in strength with increasing $w / c$ ratio is shown in Figure 13 (the minimum value of $w / c=0.54$ was taken as a reference).

After the regression analysis, excellent linear dependence can be observed, and high coefficients of determination $\left(R^{2}=0.95 \div 0.99\right)$ confirm this, Figure 12 . These lines are almost parallel. However, with the increase in the percentage of fillers, a slightly higher coefficient of direction was observed. Mixtures containing $30 \%$ of fillers have about $10 \%$ higher mentioned coefficient compared to the reference mixtures, while those with $45 \%$ replacement have this coefficient higher by about $18 \%$. That indicates a slightly greater reduction in the strength of mixtures in which the cement is partially replaced by a filler (in relative terms, due to the higher strength of these samples, the percentage drop is smaller).

On average, due to the increase in the value of $w / c$ ratio for every 0.1 , there is a decrease in strength by about $8.5,9.5$, and $10 \mathrm{MPa}$, for mixtures with 0,30 , and $45 \%$ of replaced cement. 
Compressive strength of green concrete with low cement and high filler content

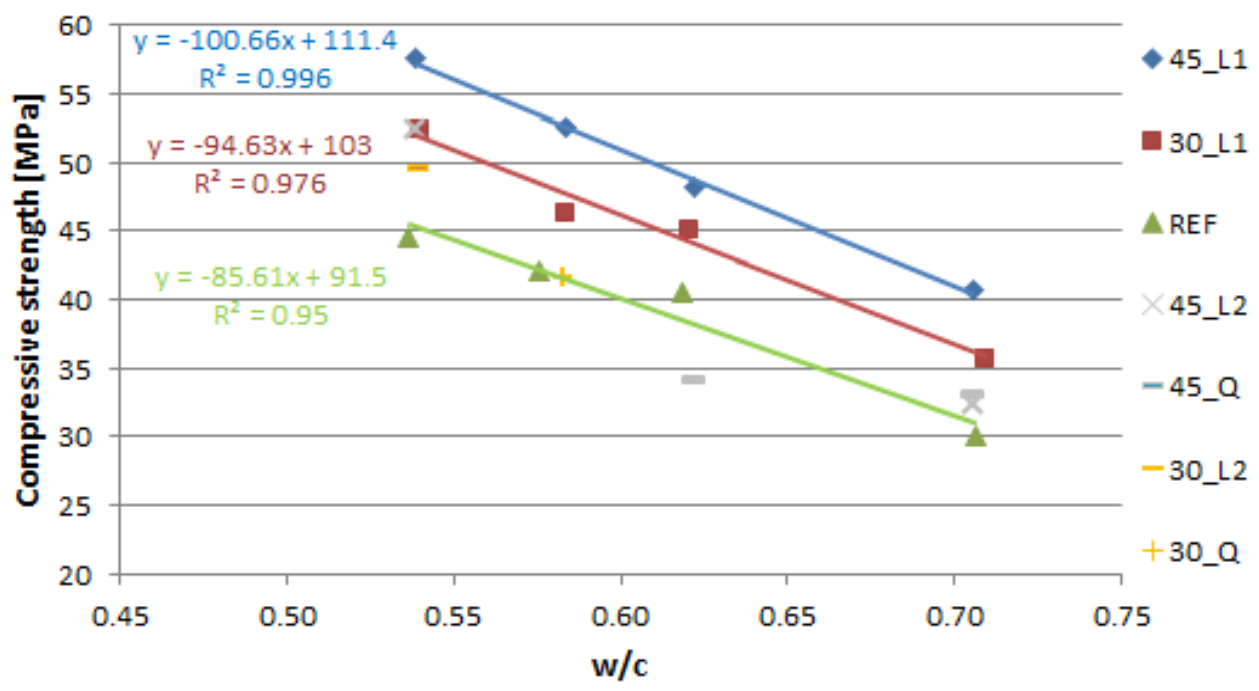

Figure 12. Compressive strength as a function of $\mathrm{w} / \mathrm{c}$ ratios and percentage of cement replacement

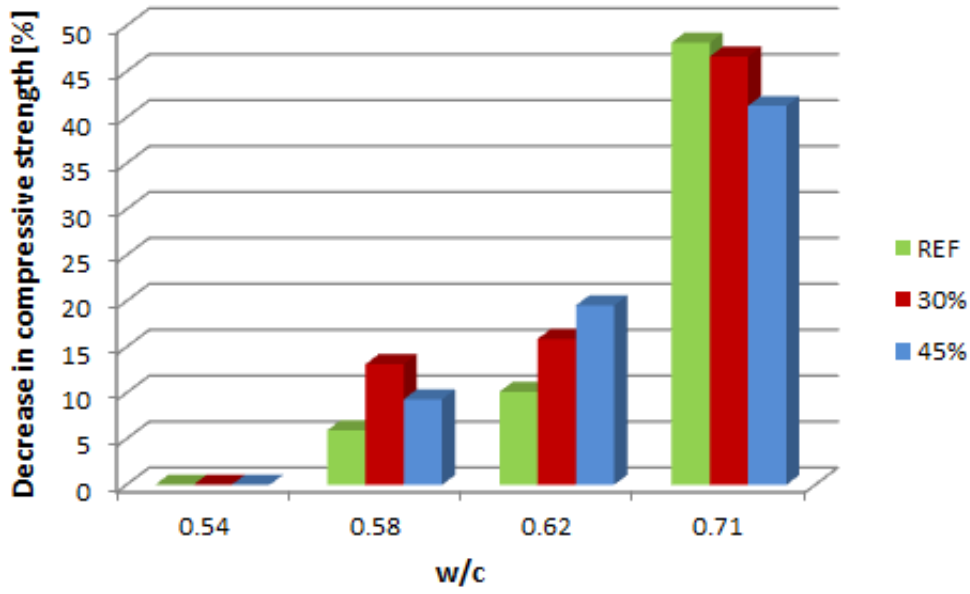

Figure 13. Influence of w/c ratio: reduction of compressive strength for different $w / c$ ratios expressed in percent, filler $L 1$

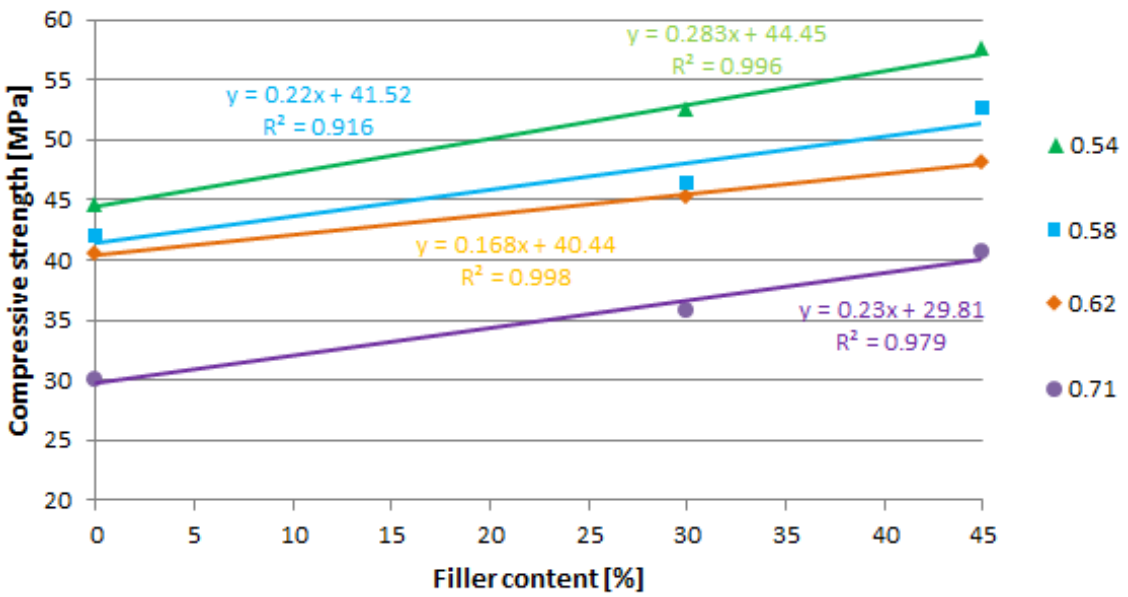

Figure 14. Compressive strength as a function of cement replacement percentage, for different $w / c$ ratios, filler L1 
In the reference samples, compared to the highest strength (44.6 MPa) obtained for the lowest w/c ratio of 0.54 , a decrease in strength of 6,10 and $48 \%$ was recorded, for $\mathrm{w} / \mathrm{c}$ ratios of $0.58 ; 0.62$, and 0.71 , respectively. In mixtures in which $30 \%$ of cement is replaced by the finest filler (L1), these reductions are 13,16 , and $46 \%$, respectively, while in the case of $45 \%$ replacement these values are 9,19 , and $41 \%$ for the same $w / c$ ratios.

In order to understand better the influence of fillers, Figure 14 shows the dependence of compressive strength of mixtures with filler L1 as a function of the percentage replacement of cement for different $w / c$ ratios. With a decrease in the amount of cement, i.e. with an increase in the filler in the mixture, a linear trend of increasing compressive strength for all w/c ratios is observed. On average, for every $10 \%$ of cement replacement, the strength increases by about 2.3 MPa. In this case, too, a high level of correlation was achieved $\left(R^{2}>0.9\right)$.

The increase in strength as a function of the percentage of cement replacement is shown in Figure 15. The figure shows an average increase in strength of $14.7 \%$ in the case of mixtures in which $30 \%$ of cement was replaced by filler, while in mixtures with $45 \%$ of cement replacement an average increase of approximately $27 \%$ was recorded.

The increase in compressive strength is a consequence of the improved particle packing density, which is to some extent reflected in the increase in the density of the samples, Figure 16. The figure shows that there is a certain correlation, but the density is a rather sensitive and insufficiently reliable parameter. Nevertheless, it can be used for possible preliminary assessment.

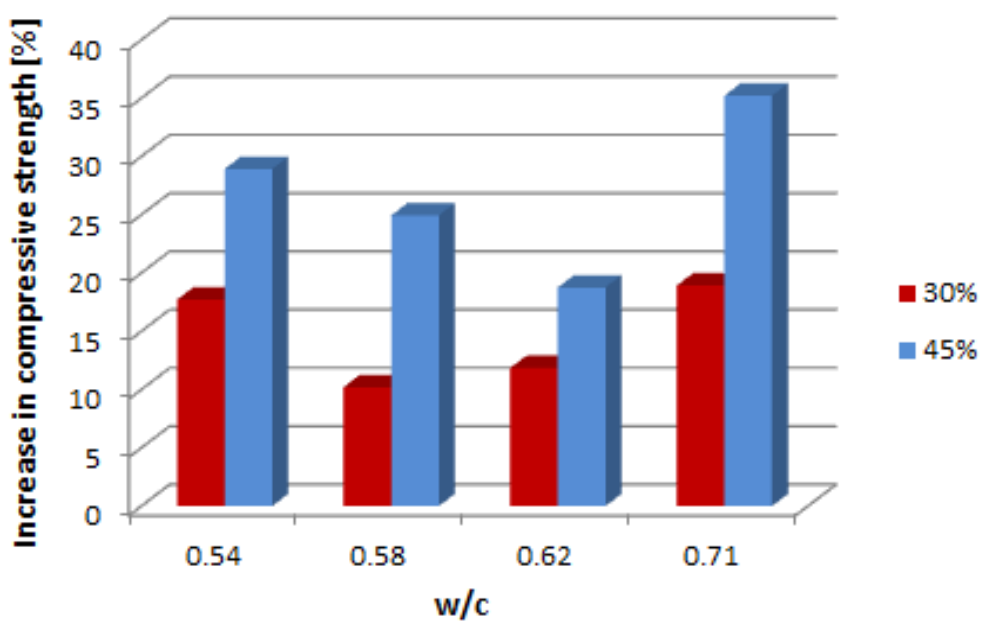

Figure 15. Influence of replacement percentage: increase in compressive strength in relation to the reference mixture depending on the replacement percentage of cement, filler $L 1$

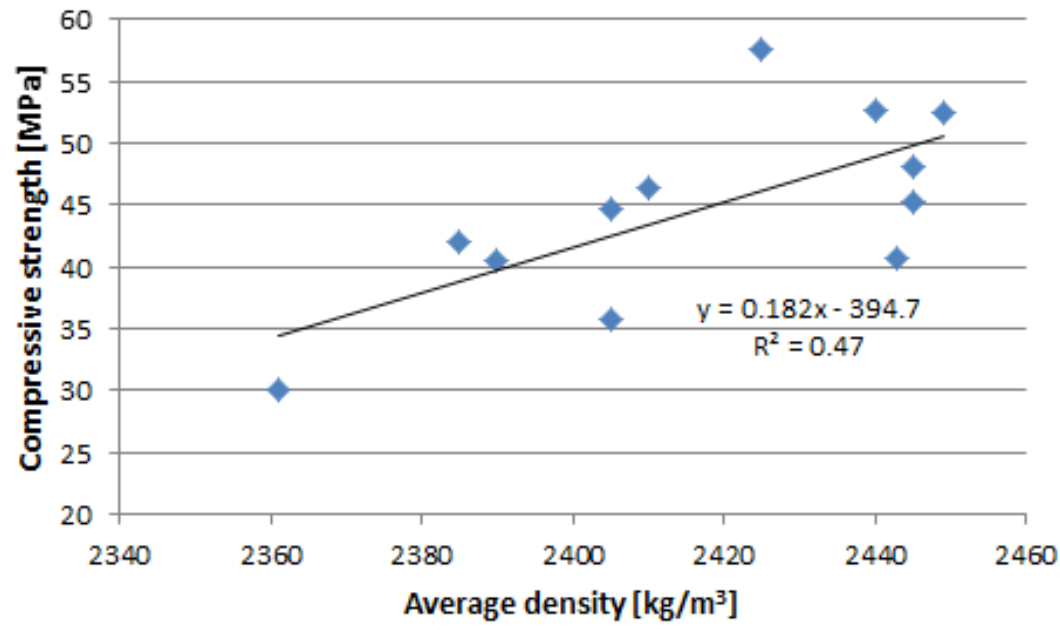

Figure 16. Compressive strength as a function of concrete density 
Analysing the samples in which larger fillers were used ( $L 2$ and $Q$ ), it was found that their strengths are lower compared to the strengths of the samples in which the finest filler (L1) was used, Figure 17. Thus, the compressive strength of concrete decreases compared to reference samples with increasing filler size, regardless of the w/c ratio and the percentage of cement replacement. In the case of L2 filler application, a decrease of $6-25 \%$ was observed. In the case of samples with quartz filler, in some cases, the decrease in strength was up to $40 \%$. The effect of filler size seems to be less pronounced in mixtures with a lower percentage of cement replacement.

It should be borne in mind that these conclusions were drawn on the basis of relatively limited number of samples, and in order to analyse in more detail the influence of filler size and to draw more reliable conclusions, it is desirable to expand the scope of experimental tests. It should be noted that larger fillers are significantly cheaper (4-5 times), so if high concrete compressive strength is not required, their application can be economically justified, provided that the problem of insufficient workability is solved.

\section{Conclusions}

In this study, green concrete mixtures were made for structural use. In the scope of the extensive test program, the influence of different percentages of cement replacement, water-cement ratio, but also the particle size of the applied filler, was analyzed.

The conducted analyses undoubtedly show the great potential of green concrete with low cement and high filler content and their potential application in reinforced concrete structures. Experimental tests have shown that it is possible to make concrete of the usual strength classes (C25/30; C30/37) and even higher, with a significantly reduced amount of cement $\left(<200 \mathrm{~kg} / \mathrm{m}^{3}\right)$. In this way, large economic savings can be achieved and the negative impact of concrete industry on the environment can be significantly reduced, especially if we take into account the amount of cement produced, which is constantly increasing.

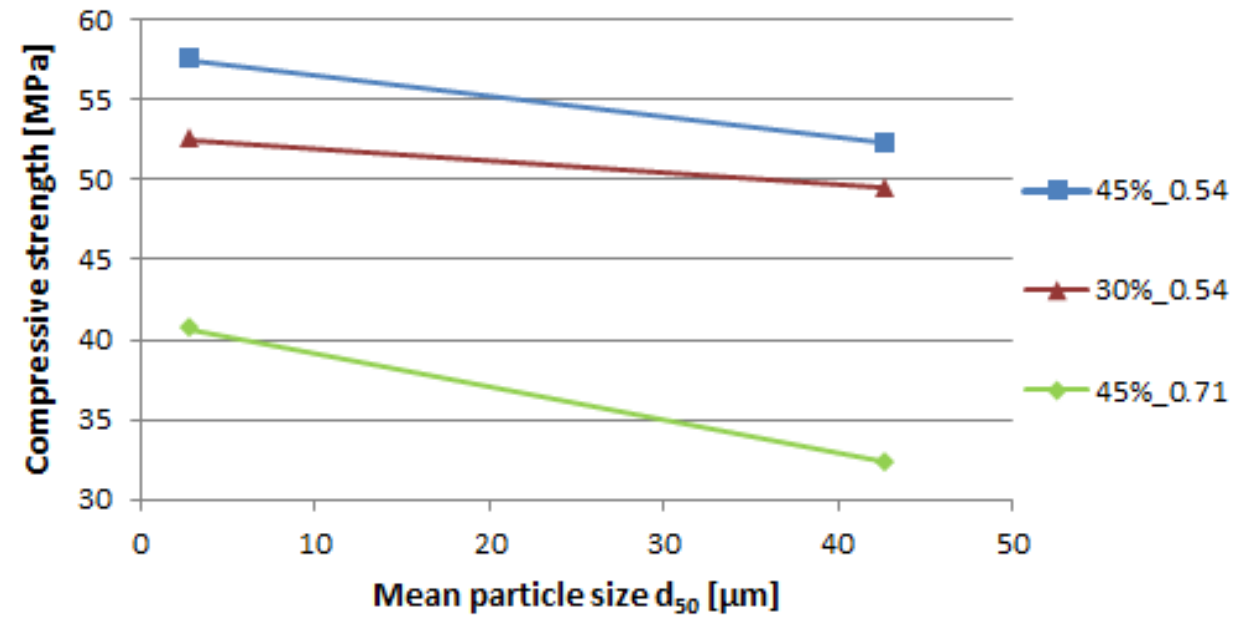

Figure 17. Influence of filler size on compressive strength of concrete

Based on the experimental results, the following conclusions can be drawn:

- One of the most important parameters in this type of concrete is the $\mathrm{w} / \mathrm{c}$ ratio, which plays a key role in most properties of concrete in the fresh and hardened state;

- The reduction of binder content often may lead to the reduction in compressive strength. In order to preserve the high compressive strength, it is necessary to keep the same $w / c$ ratio in relation to the reference mixture;

- It should be kept in mind that due to the decrease in the value of $w / c$ ratio for every 0.1 , there is a linear increase in strength on average about $9 \mathrm{MPa}$ in all samples, and the increase is slightly smaller in mixtures with higher percentage of cement replacement;

- The application of one of the models to improve the particle packing density is very desirable, and even fairly simple models such as the model proposed by Funk and Dinger provide very good results;
- With the increase of the percentage of cement replacement, at the same $\mathrm{w} / \mathrm{c}$ ratio, the compressive strength of concrete increases, which is the consequence of the increase of particle packing, however, the workability of mixtures is disturbed, which is very important for practical application;

- On average, for every $10 \%$ of cement replacement, the strength increases by about 2.3 MPa. Thus, in samples with $30 \%$ of replaced cement, an increase of $14.7 \%$ was observed on average, while in those with $45 \%$ of replaced cement, an average strength increase of approximately $27 \%$ was recorded;

- Great attention should be paid to solving the problem of workability. Therefore, the use of new generation superplasticizers and possible increase in the content of powder component should be pointed out as potential solutions, which can be achieved by simply adopting a lower exponent value in the Funk and Dinger model. The combination of these two proposals can give an optimal 
solution. The use of second-generation superplasticizers contributes to the improvement of workability only to a certain extent, and overdosing can be economically unprofitable.

- If it is not necessary to obtain high-strength concrete, workability can be improved more simply and economically by correcting the w/c ratio. In contrast, if it is necessary to achieve high compressive strengths of concrete, it is possible to use cement of finer grades and possibly higher class, with a reduction in $\mathrm{w} / \mathrm{c}$ ratio;

- When it comes to filler size, preference should certainly be given to finer fillers that, regardless of the $w / c$ ratio, have a positive effect on workability, but also on strength (in some cases an increase of up to $40 \%$ ). This effect is more pronounced with higher percentage of cement replacement;

- The proposed equations obtained by regression analysis can be used for practical assessment of the influence of certain parameters on the compressive strength of this type of green concrete;

- Further research should focus on forming a database to draw more detailed conclusions and suggest more reliable equations.

\section{Acknowledgements}

This work was supported by the Ministry for Education, Science and Technology, Republic of Serbia (grant number TR36017); this support is gratefully acknowledged.

Also, the authors are grateful to: Lafarge Srbija BFC Ltd., Beočin; OmyaVenčac Ltd., Aranđelovac; ELITA-COP Ltd. Zemun; TKK Ltd. Beograd; Sika Srbija Ltd.; Dr. Smija Marković, Institute of Technical Sciences of SASA.

\section{References}

[1] R. Warburton, Global Warming Has Concrete Problem When It Comes to CO2, EcoRI News. 8 (2019). https://www.ecori.org/climate-

change/2019/10/4/global-warming-has-a-co2ncreteproblem. Accessed 12.3.2021.

[2] D. Perilli, Emissions trading in Europe and China, Glob. Cem. 2 (2021). https://www.globalcement.com/news /item/11989-emissions-trading-in-europe-and-china. Accessed 1.4.2021.

[3] Working group UNEP-SBCI, Eco-efficient cements: Potential economically viable solutions for a low-CO2 cement-based materials industry, United Nations Environ.Progr.- Sustain.Build.Clim. Initiat. (2015) 1-64. https://wedocs.unep.org/bitstream/handle/20.500.118 22/25281/eco_efficient_cements.pdf.

[4] L. Wood, Global Cement and Concrete Products Market Report (2021 to 2030) - COVID-19 Impact and Recovery, Res. Mark. (2021). https://www.prnewswire .com/news-releases/global-cement-and-concreteproducts-market-report-2021-to-2030---covid-19impact-and-recovery-301217983.html.Accessed 10.4.2021.

[5] N. Müller, J. Harnisch, A blueprint for a climate friendly cement industry, Rep. WWF-Lafarge Conserv. Partnership. (2008). https://awsassets.panda .org/downloads/englishsummary_Ir_pdf.pdf.
[6] WBCSD, Cement technology roadmap shows how the path to achieve CO2 reductions up to $24 \%$ by 2050 , World Bus. Counc. Sustain. Dev. 4 (2018). https://www.iea.org/news/cement-technologyroadmap-plots-path-to-cutting-co2-emissions-24-by2050. Accessed 11.2.2021.

[7] A. Nazari, J.G. Sanjayan, Handbook of Low Carbon Concrete, Elsevier. 1st Editio (2016). isbn: 9780128045404.

[8] N. Tošić, S. Marinković, T. Dašić, M. Stanić, Multicriteria optimization of natural and recycled aggregate concrete for structural use, J. Clean. Prod. 87 (2015) 766-776. doi:10.1016/j.jclepro.2014.10.070.

[9] D.L. Summerbell, C.Y. Barlow, J.M. Cullen, Potential reduction of carbon emissions by performance improvement: A cement industry case study, J. Clean. Prod. 135 (2016) 1327-1339. doi:10.1016/j.jclepro .2016.06.155.

[10] R. McCaffrey, The global cement industry in 2050 , Glob. Cem. Mag. (2019) 10-18.

[11] CEMBUREAU, Cementing the European Green Deal REACHING CLIMATE NEUTRALITY ALONG THE CEMENT AND CONCRETE VALUE CHAIN BY 2050, Eur. Cem. Assoc. Brussels. (2020) 1-38. https://cembureau.eu/media/kuxd32gi/cembureau2050-roadmap_final-version_web.pdf.

[12] J. Dragaš, I. Ignjatović, N. Tošić, S. Marinković, Mechanical and time-dependent properties of highvolume fly ash concrete for structural use, Mag. Concr. Res. 68 (2016) 632-645. doi:10.1680/jmacr.15.00384.

[13] N. Tošić, S. Marinković, N. Pecić, I. Ignjatović, J. Dragaš, Long-term behaviour of reinforced beams made with natural or recycled aggregate concrete and high-volume fly ash concrete, Constr. Build. Mater. 176 (2018) 344-358. doi:10.1016/j.conbuildmat.2018 .05 .002 .

[14] J. Provis, J.S.J. van Deventer, Geopolymers: Structure, processing, properties and industrial applications, Woodhead Publishing Limited, Abington Hall, Granta Park, Great Abington, Cambridge CB21 6AH, UK, 2009.

[15] V.M. John, B.L. Damineli, M. Quattrone, R.G. Pileggi, Fillers in cementitious materials - Experience, recent advances and future potential, Cem. Concr. Res. 114 (2018) 65-78. doi:10.1016/j.cemconres.2017.09.013.

[16] T. Proske, S. Hainer, M. Rezvani, C.A. Graubner, EcoFriendly Concretes With Reduced Water and Cement Content: Mix Design Principles and Experimental Tests, Handb. Low Carbon Concr. (2017) 63-87. doi:10.1016/B978-0-12-804524-4.00004-X.

[17] S. Palm, T. Proske, M. Rezvani, S. Hainer, C. Müller, C.A. Graubner, Cements with a high limestone content - Mechanical properties, durability and ecological characteristics of the concrete, Constr. Build. Mater. 119 (2016) 308-318. doi:10.1016/j.conbuildmat .2016.05.009.

[18] K.L. Scrivener, V.M. John, E.M. Gartner, Eco-efficient cements: Potential economically viable solutions for a low-CO2 cement-based materials industry, Cem. Concr. Res. 114 (2018) 2-26. doi:10.1016/j .cemconres.2018.03.015. 
[19] S.A. Miller, A. Horvath, P.J.M. Monteiro, Readily implementable techniques can cut annual $\mathrm{CO} 2$ emissions from the production of concrete by over 20\%, Environ. Res. Lett. 11 (2016). doi:10.1088/17489326/11/7/074029.

[20] Lafarge Srbija d.o.o., "The 2030 Plan" The Lafarge Holcim Sustainability Strategy, (n.d.). https://www.lafarge.rs/sites/serbia/files/atoms/files/lafa rgeholcim-the_2030_plan-leaflet.pdf. Accessed 6.4.2021.

[21] P. Thongsanitgarn, W. Wongkeo, S. Sinthupinyo, A. Chaipanich, Effect of limestone powders on compressive strength and setting time of Portlandlimestone cement pastes, in: TIChE Int. Conf. 2011, Songkhla Thail., 2011: pp. 1-4. doi:10.4028/www.scientific.net/AMR.343-344.322.

[22] C. Vogt, Ultrafine particles in concrete - Influence of ultrafine particles on concrete properties and application to concrete mix design, Sch. Archit. Built Environ. Div. Concr. Struct. (2010) 177. Doctoral dissertation.

[23] S.H. Kang, Y. Jeong, K.H. Tan, J. Moon, The use of limestone to replace physical filler of quartz powder in UHPFRC, Cem. Concr. Compos. 94 (2018) 238-247. doi:10.1016/j.cemconcomp.2018.09.013.

[24] National Park Service USA, Idaho Arrowrock Dam. (n.d.). https://www.nps.gov/articles/idaho-arrowrockdam.htm. Accessed 1.4.2021.

[25] Bureau of Reclamation, Elephant Butte Dam. (n.d.). https://www.usbr.gov/projects/index.php?id=94. Accessed 1.4.2021.

[26] R. Davis, W. Hanna, E. Brown, Strength, Volume Changes, and Sulfate Resistance of Mortars Containing Portland-Pozzolan Cements, in: Symp. Use Pozzolanic Mater. Mortars Concr., ASTM International, 100 Barr Harbor Drive, PO Box C700, West Conshohocken, PA 19428-2959, 1950: pp. 131-152. doi:10.1520/STP39407S.

[27] P.D. Tennis, M.D.A. Thomas, W.J. Weiss, State-ofthe-Art Report on Use of Limestone in Cements at Levels of up to $15 \%$, Portl. Cem. Assoc. PCA R\&D SN (2011) 78.

[28] P. Hawkins, P. Tennis, R. Detwiler, The Use of Limestone in Portland Cement: A State-of-the-Art Review, Portl. Cem. Assoc. Skokie, Illinois, USA. (2005) 44.

[29] WBCSD Cement Sustainability Initiative, GNR Project Reporting CO2, World Bus. Counc. Sustain. Dev. (2018). https://gccassociation.org/gnr/. Accessed 7.4.2021.

[30] EN 197-1, Cement - Part 1: Composition, specifications and conformity criteria for common cements Ciment, Eur. Comm. Stand. Brussels. (2011).

[31] EN 12620:2010, Aggregates for concrete, Eur. Comm. Stand. Brussels. (2010).

[32] M. Rezvani, T. Proske, S. Hainer, C. Graubner, Rheology of eco-friendly self-compacting concretes with limestone-rich cements, in: Proc. Int. Symp. EcoCrete, Reykjavik, Isl., 2014: p. 8.
[33] M. Bederina, Z. Makhloufi, T. Bouziani, Effect of limestone fillers the physic-mechanical properties of limestone concrete, Phys. Procedia. 21 (2011) 28-34. doi:10.1016/j.phpro.2011.10.005.

[34] V. Bonavetti, H. Donza, G. Menéndez, O. Cabrera, E.F. Irassar, Limestone filler cement in low w/c concrete: A rational use of energy, Cem. Concr. Res. 33 (2003) 865-871. doi:10.1016/S00088846(02)01087-6

[35] J.J. Chen, A.K.H. Kwan, Y. Jiang, Adding limestone fines as cement paste replacement to reduce water permeability and sorptivity of concrete, Constr. Build. Mater. 56 (2014) 87-93. doi:10.1016/j.conbuildmat .2014.01.066.

[36] J.J. Chen, A.K.H. Kwan, Y. Jiang, Adding limestone fines as cement paste replacement to reduce water permeability and sorptivity of concrete, Mag. Concr. Res. 65 (2015) 942-950. doi:10.1680/macr.13.00028.

[37] Z. Zhang, Q. Wang, H. Chen, Properties of highvolume limestone powder concrete under standard curing and steam-curing conditions, Powder Technol. 301 (2016) 16-25. doi:10.1016/j.powtec.2016.05.054.

[38] T. Proske, S. Hainer, M. Rezvani, C.A. Graubner, Ecofriendly concretes with reduced water and cement contents - Mix design principles and laboratory tests, Cem. Concr. Res. 51 (2013) 38-46. doi:10.1016/j.cemconres.2013.04.011.

[39] D. Wang, C. Shi, N. Farzadnia, Z. Shi, H. Jia, A review on effects of limestone powder on the properties of concrete, Constr. Build. Mater. 192 (2018) 153-166. doi:10.1016/j.conbuildmat.2018.10.119.

[40] B.L. Damineli, Conceitos para formulação de concretos com baixo consumo de ligantes: controle reológico, empacotamento e dispersão de partículas - Concepts for Formulation of Low-binder Concretes, Universidade de São Paulo, Esc. Politécnica, São Paulo. (2013). Tese de Doutorado.

[41] M. Lundgren, Limestone Filler as Addition in Cement Mortars: Influence on the Early-Age Strength Development at Low Temperature, Nord. Concr. Res. (2004) 50-63.

[42] M. Rezvani, T. Proske, S. Hainer, C. Graubner, Limestone-Rich Cements for Sustainable Concrete Structures - Limestone-Rich Cements for Sustainable Concrete Structures - Mechanical Properties, (2014) $1-8$.

[43] T. Proske, S. Hainer, M. Rezvani, C.A. Graubner, Ecofriendly concretes with reduced water and cement content - Mix design principles and application in practice, Constr. Build. Mater. 67 (2014) 413-421. doi:10.1016/j.conbuildmat.2013.12.066.

[44] T. Proske, M. Rezvani, S. Palm, C. Müller, C.A. Graubner, Concretes made of efficient multi-composite cements with slag and limestone, Cem. Concr. Compos. 89 (2018) 107-119. doi:10.1016/j .cemconcomp.2018.02.012.

[45] M. Rezvani, T. Proske, C.A. Graubner, Shrinkage of Mortar Samples Made of Limestone-Rich Cements, ASCE, CONCREEP. 10 (2014) 1476-1484. 
[46] H.S. Mueller, M. Haist, J.S. Moffatt, M. Vogel, Design, Material Properties and Structural Performance of Sustainable Concrete, Procedia Eng. 171 (2017) 2232. doi:10.1016/j.proeng.2017.01.306.

[47] S.A.A.M. Fennis, Design of Ecological Concrete by Particle Packing Optimization, Tech. Univ. Delft. (2011). Doctoral dissertation.

[48] SRPS EN 12350-2: Ispitivanje svežeg betona - Deo 2: Ispitivanje sleganja, Inst. Za Stand. Srb. (2010).

[49] J.E. Brewe, J.J. Myers, Particle Size Optimization for Reduced Cement High Strength, in: Conf. Proc. PClNBC Bridg. Life 2005, Palm Springs, Calif., 2005: pp. 1-18. pdf.
[50] EN 12390-1:2004, Shape, dimensions and other requirements for specimens and moulds, Eur. Comm. Stand. Brussels. (2004).

[51] EN 12390-2:2000, Testing hardened concrete - Part 2: Making and curing specimens for strength tests, Eur. Comm. Stand. Brussels. (2000).

[52] EN 12390-3:2001, Testing hardened concrete - Part 3: Compressive strength of test specimens, Eur. Comm. Stand. Brussels. (2001). 